\title{
Kesesuaian Nilai C-Reactive Protein dan Procalcitonin dalam Diagnosis Pneumonia Berat pada Anak
}

\author{
Irawati, Heda Melinda, Ponpon S. Idjradinata \\ Bagian Ilmu Kesehatan Anak Fakultas Kedokteran Universitas Padjadjaran/Rumah Sakit Dr. Hasan \\ Sadikin, Bandung
}

\begin{abstract}
Latar belakang. Penyebab pneumonia sulit dibedakan berdasarkan klinis, radiologis, dan pemeriksaan darah rutin, sedangkan pemeriksaan biakan darah memerlukan waktu lama dengan hasil positif 10\%-30\% kasus. Baku emas biopsi jaringan paru bersifat invasif dan tidak diindikasikan. Procalcitonin merupakan penanda untuk memperkirakan infeksi bakteri dengan sensitivitas dan spesifisitas paling baik.

Tujuan Penelitian. Mengetahui kesesuaian C-reactive protein (CRP) dan procalcitonin dalam diagnosis pneumonia berat pada anak, sehingga pemeriksaan CRP dapat digunakan sebagai pengganti procalcitonin.

Metode. Penelitian observasional analitik dengan rancangan potong lintang dilakukan di Unit Gawat Darurat dan Rawat Inap Bagian Ilmu Kesehatan Anak Fakultas Kedokteran Universitas Padjadjaran/Rumah Sakit Hasan Sadikin Bandung dan Rumah Sakit Umum Cibabat Cimahi pada bulan Mei-Juni 2010. Pemeriksaan CRP dan procalcitonin dilakukan saat didiagnosis pneumonia berat pada 29 anak berusia 2-60 bulan. Analisis statistik menggunakan kurva analisis receiver operating characteristic (ROC) untuk mengetahui nilai CRP yang dapat digunakan untuk memprediksi infeksi bakteri dan analisis keserasian Kappa untuk menguji kesesuaian antara nilai CRP dan procalcitonin.

Hasil. Didapatkan cut off point CRP yang dapat digunakan sebagai prediksi infeksi bakteri adalah $>8 \mathrm{mg} / \mathrm{L}$ dengan sensitivitas $68,2 \%$, spesifisitas $100 \%$ dan akurasi $75,9 \%$ dan adanya kesesuaian yang baik antara nilai CRP dan procalcitonin, yaitu $\mathrm{K}=0,508$.

Kesimpulan. Terdapat kesesuaian nilai CRP dan procalcitonin dalam diagnosis pneumonia berat pada anak, sehingga CRP dapat digunakan untuk menggantikan procalcitonin. (Sari Pediatri 2010;12(2):78-81).
\end{abstract}

Kata kunci: $C$-reactive protein, pneumonia berat, procalcitonin, anak

Alamat korespondensi:

Dr. Irawati. Bagian Ilmu Kesehatan Anak Fakultas Kedokteran Universitas Padjadjaran/Rumah Sakit Dr. Hasan Sadikin Jl. Pasteur No. 38 Bandung 40161, Indonesia. Telp.022-2035957. email: irawati_1@yahoo.com

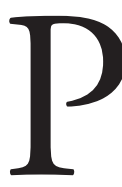
neumonia merupakan salah satu penyebab kematian tersering pada anak di bawah usia 5 tahun. Di negara berkembang, dari 1000 anak terdapat 100-150 kasus pneumonia berat dalam 5 tahun pertama kehidupan dan 21\% berakibat kematian. ${ }^{1}$ Di negara maju seperti Eropa 
Irawati dkk: Kesesuaian nilai c-reactive protein dan procalcitonin dalam diagnosis pneumonia berat pada anak

dan Amerika Utara dilaporkan insidens pneumonia berkisar 34-40 kasus per 1.000 anak. ${ }^{2}$ Berdasarkan Profil Kesehatan Indonesia 2007, dari 31 provinsi di Indonesia terdapat 477.420 balita pneumonia dan berturut-turut menyebabkan kematian bayi dan balita sebesar 22,3\% dan $23,6 \% .^{3}$

Penyebab pneumonia sulit dibedakan berdasarkan manifestasi klinis, radiologis, dan pemeriksaan darah, sedangkan pemeriksaan biakan darah memerlukan waktu lama dan mendapatkan hasil positif hanya pada $10-30 \%$ pasien, ${ }^{4-6}$ sementara baku emas biopsi jaringan paru bersifat invasif dan tidak diindikasikan. ${ }^{5}$ Pemberian antibiotik pada pneumonia bakteri sangat penting karena penundaan antibiotik akan meningkatkan mortalitas, sedangkan pemberian antibiotik yang tidak seharusnya dapat meningkatkan resistensi. ${ }^{7,8}$ Maka diperlukan penanda yang dapat segera menentukan diagnosis pneumonia bakteri, sehingga pemberian antibiotik menjadi lebih tepat. Saat ini penanda yang paling baik digunakan untuk memprediksi infeksi bakteri adalah procalcitonin. ${ }^{9,10}$ Procalcitonin adalah suatu substansi mirip sitokin yang dilepaskan oleh berbagai sel parenkim (hati, ginjal, adiposit, dan monosit) sebagai respons terhadap toksin mikroba dan beberapa mediator proinflamasi inang tertentu (IL-1 $\beta$, TNF- $\alpha$, dan IL-6). ${ }^{9,10}$

Berdasarkan penelitian sebelumnya $C$-reactive protein (CRP) juga dapat digunakan sebagai penanda untuk memprediksi infeksi bakteri, walaupun procalcitonin merupakan penanda yang lebih baik. ${ }^{8,11}$ Mengingat pemeriksaan procalcitonin mahal, maka ingin diketahui apakah terdapat kesesuaian nilai CRP dan procalcitonin dalam diagnosis pneumonia berat pada anak, sehingga pemeriksaan CRP dapat digunakan sebagai pengganti procalcitonin.

\section{Metode}

Penelitian yang dilakukan merupakan penelitian observasional analitik dengan rancangan potong lintang yang dilaksanakan di Instalasi Gawat Darurat/ Rawat Inap Bagian Ilmu Kesehatan Anak Fakultas Kedokteran Universitas Padjadjaran/Rumah Sakit Hasan Sadikin Bandung dan Rumah Sakit Umum Cibabat Cimahi pada bulan Mei-Juni 2010. Kriteria inklusi adalah anak usia 2-60 bulan yang didiagnosis pneumonia berat berdasarkan kriteria World Health
Organization (WHO)-Departemen Kesehatan Republik Indonesia (Depkes RI) 2009, dan mendapat persetujuan tertulis dari orangtua untuk ikut dalam penelitian setelah diberikan penjelasan (informed consent).

Kriteria eksklusi adalah pasien imunokompromais berat, tuberkulosis (TB), sedang mendapatkan terapi imunosupresif, dan pasien pneumonia nosokomial. Faktor perancu adalah pasien pneumonia yang telah mendapatkan antibiotik sebelumnya. Kriteria pneumonia berat adalah anak dengan batuk dan atau kesukaran bernapas ditambah minimal salah satu tanda kepala terangguk-angguk, pernapasan cuping hidung, tarikan ke dalam dinding dada bagian bawah, dan foto dada menunjukkan gambaran pneumonia (infiltrat luas, konsolidasi). Selain itu didapatkan pula tanda berupa napas cepat, grunting (pada bayi muda), auskultasi dada terdengar ronki basah, suara pernapasan menurun, atau suara pernapasan bronkial. $^{12}$

Pada semua subjek dilakukan pengambilan darah $3 \mathrm{~mL}$ untuk pemeriksaan kadar procalcitonin dengan metode procalcitonin elecsys memakai cara electrochemiluminescence assay (ECLIA), rentang nilai normal 0,02-100 $\mathrm{ng} / \mathrm{mL}$ dan CRP dengan metode CRP latex, rentang nilai normal 1,00-250 mg/L, pada saat didiagnosis pneumonia berat ditegakkan. Cut-off point procalcitonin untuk membedakan infeksi bakteri dan virus diambil berdasarkan penelitian sebelumnya yaitu $0,5 \mathrm{ng} / \mathrm{mL} .{ }^{13}$

Analisis statistik menggunakan kurva analisis receiver operating characteristic (ROC) untuk mengetahui nilai CRP yang dapat digunakan untuk memprediksi infeksi bakteri dan analisis keserasian Kappa untuk menguji kesesuaian antara nilai CRP dan procalcitonin. Kemaknaan hasil uji ditentukan berdasarkan nilai $\mathrm{p}<0,05$. Data dianalisis menggunakan SPSS versi 17.0.

Proporsal penelitian telah disetujui oleh Komite Etik Fakultas Kedokteran Universitas Padjadjaran/ Rumah Sakit Hasan Sadikin Bandung.

\section{Hasil}

Subjek terdiri dari 29 pasien yang memenuhi kriteria inklusi, 13 anak laki-laki dan 16 anak perempuan. Kelompok usia 2-11 bulan terdiri dari 21 anak dan 8 anak kelompok usia 12-60 bulan. 
Berdasarkan penelitian yang telah dilakukan sebelumnya digunakan cut-off point procalcitonin 0,5 $\mathrm{ng} / \mathrm{mL}$ sebagai prediksi adanya infeksi bakteri. Untuk mengetahui nilai CRP yang dapat dipakai sebagai prediksi infeksi bakteri digunakan perhitungan melalui kurva analisis ROC yaitu dengan menghubungkan besarnya 100 - spesifisitas dengan sensitivitas. Kurva ROC tertera pada Gambar 1.

Pada Gambar 1 didapat cut-off point CRP yang dapat digunakan sebagai prediksi infeksi bukan bakteri adalah $\leq 8 \mathrm{mg} / \mathrm{L}$ dengan sensitivitas $68,2 \%$, spesifisitas $100 \%$, dan akurasi $75,9 \%$. Untuk lebih jelas hubungan nilai CRP dengan procalcitonin disajikan dalam tabel $2 \times 2$ (Tabel 1.)

Berdasarkan hasil pada Tabel 1 dilakukan analisis untuk derajat kesesuaian antara nilai CRP dan procalcitonin dengan menggunakan analisis keserasian Kappa, didapatkan kesesuaian yang baik yaitu $\mathrm{K}=0,508$.

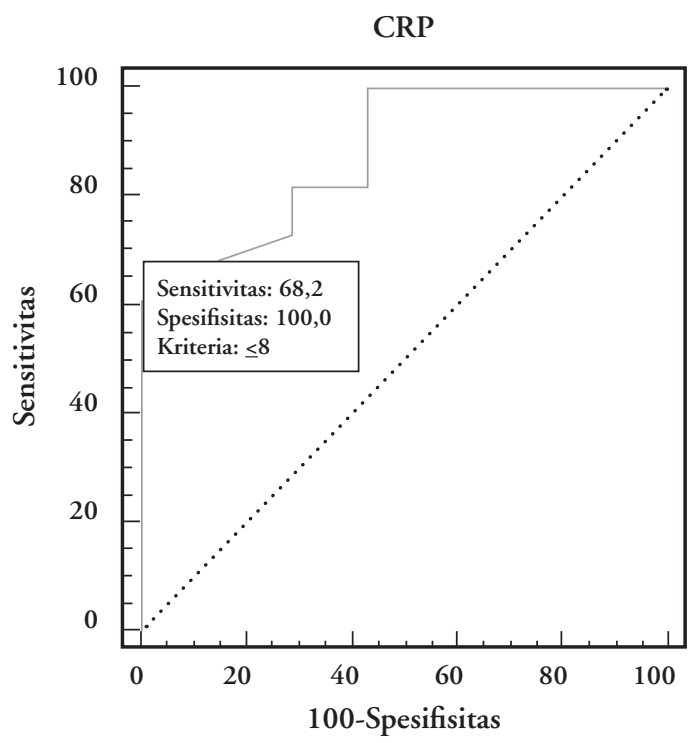

Gambar 1. Kurva ROC nilai CRP serum untuk memprediksi pneumonia bakteri

Tabel 1. Hubungan nilai titik potong CRP dengan nilai procalcitonin serum

\begin{tabular}{lcccc}
\hline & \multicolumn{2}{c}{ Procalcitonin } & & \\
\cline { 2 - 3 } $\mathrm{CRP}(\mathrm{mg} / \mathrm{L})$ & $<0,5(\mathrm{ng} / \mathrm{mL})$ & $>0,5(\mathrm{ng} / \mathrm{mL})$ & & $\mathrm{p}$ \\
\hline & & & & \\
$\leq 8$ & 15 & 0 & 15 & 0,002 \\
$>8$ & 7 & 7 & 14 & \\
\hline
\end{tabular}

Keterangan: * uji eksak Fisher

\section{Pembahasan}

Penyebab pneumonia karena infeksi bakteri atau virus sulit dibedakan berdasarkan klinis, laboratorium, dan foto toraks, tetapi kebanyakan pneumonia berat disebabkan oleh infeksi bakteri. ${ }^{2}$ Pneumonia yang dicurigai disebabkan infeksi bakteri dengan nilai procalcitonin $>0,5 \mathrm{ng} / \mathrm{mL}$ terdapat pada 7 pasien dan semuanya memenuhi nilai CRP $>8 \mathrm{mg} / \mathrm{L}$, sehingga cut-off point untuk CRP yang dapat digunakan untuk memprediksi infeksi bakteri adalah $>8 \mathrm{mg} / \mathrm{L}$. Namun cut-off point CRP $>8 \mathrm{mg} / \mathrm{L}$ berbeda dengan penelitian-penelitian sebelumnya. Pada penelitian Moulin $\mathrm{dkk}^{8}$ didapatkan cut-off point CRP >20 mg/L untuk memprediksi bakteri. Penelitian Holm $\mathrm{dkk}^{13}$ juga mendapatkan hasil cut-off point yang sama, sedangkan penelitian lain mendapatkan nilai cut-off point $>80 \mathrm{mg} / \mathrm{L}$. Meskipun pada infeksi bakteri terjadi peningkatan CRP dan procalcitonin, tetapi pada penelitian-penelitian sebelumnya juga didapatkan hasil bahwa CRP mempunyai sensitivitas dan spesifisitas yang lebih rendah dibandingkan procalcitonin. Hal tersebut tampak pada penelitian Simon $\mathrm{dkk}^{11}$ yang melaporkan sensitivitas dan spesifisitas procalcitonin lebih tinggi dibandingkan CRP untuk membedakan infeksi bakteri dengan infeksi virus ( $92 \%$ vs $86 \%$ dan $73 \%$ vs $70 \%$ ). Pada penelitian lain dari 88 anak pneumonia (cut-off point procalcitonin $1 \mu \mathrm{g} / \mathrm{L}$ ) didapatkan procalcitonin lebih sensitif dan spesifik dibandingkan CRP (cut-off point $20 \mathrm{mg} / \mathrm{L}$ ), IL-6, ataupun jumlah leukosit dalam membedakan infeksi bakteri dengan virus. ${ }^{8}$ Penelitian lain juga mendapatkan hasil bahwa procalcitonin (cutoffpoint $0,25 \mu \mathrm{g} / \mathrm{L}$ ) mempunyai keakuratan diagnosis lebih tinggi dibandingkan CRP dan jumlah leukosit total dapat membedakan pneumonia komunitas dari penyebab noninfeksi. ${ }^{14}$

Setelah dilakukan analisis untuk menilai derajat kesesuaian nilai CRP dan procalcitonin, didapatkan adanya kesesuaian yang cukup baik sehingga walaupun CRP mempunyai nilai sensitivitas dan spesifisitas yang lebih rendah daripada procalcitonin, CRP masih dapat digunakan untuk memprediksi infeksi bakteri pada pneumonia berat.

Disimpulkan bahwa terdapat kesesuaian nilai CRP dengan procalcitonin dalam diagnosis pneumonia berat pada anak, sehingga CRP dapat digunakan untuk menggantikan procalcitonin apabila pemeriksaan procalcitonin tidak tersedia. 
Irawati dkk: Kesesuaian nilai c-reactive protein dan procalcitonin dalam diagnosis pneumonia berat pada anak

\section{Daftar pustaka}

1. Scott JA, Brooks WA, Peiris M, Holtzman D, Mulholland EK. Pneumonia research to reduce childhood mortality in the developing world. J Clin Invest 2008;18:1291-300.

2. Ostapchuk M, Roberts DM, Haddy R. Communityacquired pneumonia in infants and children. Am Fam Physician 2004;70:899-908.

3. Departemen Kesehatan Republik Indonesia. Profil kesehatan Indonesia 2007. Jakarta: Depkes RI; 2007.

4. Virkki R, Juven T, Rikalainen H, Svedstrom E, Mertsola J, Ruuskanen O. Differentiation of bacterial and viral pneumonia in children. Thorax 2002;57:438-41

5. Sectish TC, Prober CG. Pneumonia. Dalam: Kliegman RM, Jenson HB, Stanton BF, penyunting. Nelson textbook of pediatrics. Edisi ke-18. Philadelphia: Saunders Elsevier; 2007. h.1795-800.

6. Kabra SK, Broor S, Lodha R, Maitrey RS, Ghosh M, Pandey RM, dkk. Can we identify acute severe viral lower respiratory tract infection clinically? Indian Pediatrics 2004;41:245-9.

7. Crain MC, Stolz D, Bingisser R, Muller C, Miedinger D, Huber PR, dkk. Procalcitonin guidance of antibiotic therapy in community-acquired pneumonia. Am J Respir Crit Care Med 2006;174:84-93.
8. Moulin F, Raymond J, Lorrot M, Marc E, Coste J, Iniguez JL, dkk. Procalcitonin in children admitted to hospital with community acquired pneumonia. Arch Dis Child 2001;84:332-6.

9. Clec'h C, Ferriere F, Karoubi P, Fosse JP, Cupa $M$, Hoang P. Diagnostic and prognostic value of procalcitonin in patients with septic shock. Crit Care Med 2004;32:1166-9.

10. Nobre V, Harbart S, Graf JD, Rohner P, Pugin J. Use of procalcitonin to shorten antibiotic treatment duration in septic patients. Am J Respir Crit Care Med 2008; 177:498-505.

11. Simon L, Gauvin F, Amre DK, Louis PS, Lacroix J. Serum procalcitonin and C-reactive protein levels as markers of bacterial infection: a systematic review and meta-analysis. CID 2004;39:206-17.

12. Buku saku pelayanan kesehatan anak di rumah sakit. Pedoman bagi rumah sakit rujukan tingkat pertama di kabupaten/kota. WHO Indonesia; 2008.

13. Holm A, Pedersen S, Nexoe N, Obel N, Nielsen L. $\mathrm{P}$, Koldkjaer O, dkk. Procalcitonin versus $\mathrm{C}$-reactive protein for predicting pneumonia in adults with lower respiratory tract infection in primary care. $\mathrm{Br} \mathrm{J}$ Gen Practice 2007;57:555-60.

14. Muller B, Harbart S, Stolz D, Bingisser R, Mueller C, Leuppi J, dkk. Diagnostic and prognostic accuracy of clinical and laboratory parameters in communityacquired pneumonia. BMC Infect Dis 2007;7:1-10. 